\title{
C-reactive protein in critically ill cancer patients with sepsis: influence of neutropenia
}

Pedro Póvoa ${ }^{1,2^{*}}$, Vicente Ces Souza-Dantas ${ }^{3}$, Márcio Soares ${ }^{3,4}$ and Jorge IF Salluh $h^{3,4}$

\begin{abstract}
Introduction: Several biomarkers have been studied in febrile neutropenia. Our aim was to assess C-reactive protein (CRP) concentration in septic critically ill cancer patients and to compare those with and without neutropenia.

Methods: A secondary analysis of a matched case-control study conducted at an oncologic medical-surgical intensive care unit (ICU) was performed, segregating patients with severe sepsis/septic shock. The impact of neutropenia on CRP concentrations at admission and during the first week of ICU stay was assessed.

Results: A total of 154 critically ill septic cancer patients, 86 with neutropenia and 68 without, were included in the present study. At ICU admission, the CRP concentration of neutropenic patients was significantly higher than in non-neutropenic patients, $25.9 \pm 11.2 \mathrm{mg} / \mathrm{dL}$ vs. $19.7 \pm 11.4 \mathrm{mg} / \mathrm{dL}(P=0.009)$. Among neutropenic patients, CRP concentrations at ICU admission were not influenced by the severity of neutropenia $\left(<100 / \mathrm{mm}^{3} \mathrm{vs} . \geq 100 / \mathrm{mm}^{3}\right.$ neutrophils), $25.1 \pm 11.6 \mathrm{mg} / \mathrm{dL}$ vs. $26.9 \pm 10.9 \mathrm{mg} / \mathrm{dL}(P=0.527)$. Time dependent analysis of CRP from Day 1 to Day 7 of antibiotic therapy showed an almost parallel decrease in both groups $(P=0.335)$, though CRP of neutropenic patients was, on average, always higher in comparison to that of non-neutropenic patients.

Conclusions: In septic critically ill cancer patients CRP concentrations are more elevated in those with neutropenia. However, the CRP course seems to be independent from the presence or absence of neutropenia.
\end{abstract}

\section{Introduction}

The frequency of cancer patients requiring intensive care has increased dramatically over the last decades [1]. Frequently, in these patients, combined mechanisms of immunosuppression coexist resulting in an increased risk for sepsis. Infection is a feared and life-threatening complication in cancer patients, in particular if neutropenia is present, that is frequently related to cancer treatments, either radiation or chemotherapy [2]. Besides, the diagnosis of infection is often difficult since the early symptoms and signs of sepsis, namely the systemic inflammatory response syndrome (SIRS), can be influenced by a number of non-infectious factors present in hemato-oncological patients [3].

Fever is probably the most commonly used clinical sign [4]. However, fever is not specific of infection since

\footnotetext{
* Correspondence: povoap@netcabo.pt

'Polyvalent Intensive Care Unit, Hospital de São Francisco Xavier, Centro Hospitalar de Lisboa Ocidental, Estrada do Forte do Alto do Duque, 1449005 Lisboa, Portugal

Full list of author information is available at the end of the article
}

some tumours as well as chemotherapy are characteristically associated with fever, and in addition steroids, used in some cancer treatments, are very effective antipyretics [5]. The white cell count (WCC) is also not very useful since it can be markedly influenced by the cancer itself as well as by the exposure to corticosteroids and chemotherapy.

As a result early manifestations of infection are often misleading, in particular in the presence of neutropenia. Moreover, untreated infections in cancer patients can rapidly lead to a fatal outcome but, treating non-infectious causes with antimicrobials is ineffective, delays the correct treatment of the underlying disease and also increases costs, toxicity and the risk for the development of bacterial resistance represent a serious complication [6].

As a result of these limitations of the current clinical and laboratory parameters in the prompt diagnosis of infection, clinical research tried to identify mediators of the inflammatory cascade [7], that might help in that diagnosis. Several potential biomarkers of infection have
C Biomed Central

() 2011 Póvoa et al.; licensee BioMed Central Ltd. This is an open access article distributed under the terms of the Creative Commons Attribution License (http://creativecommons.org/licenses/by/2.0), w.hich permits unrestricted use, distribution, and reproduction in any medium, provided the original work is properly cited. 
been assessed in the evaluation of febrile neutropenic patients, like interleukin (IL)-6, IL-8, serum amyloid A, C-reactive protein $(\mathrm{CRP})$, procalcitonin $[8,9]$, with diverse results.

Almost all studies assessed the diagnostic and/or prognostic performance of different biomarkers of infection in septic cancer patients, namely with febrile neutropenia. However, non-neutropenic cancer patients with sepsis are usually excluded from these studies. In the present study, our aim was to assess in septic cancer patients the concentrations of a widely used biomarker of infection, CRP, comparing the baseline concentrations and response to antibiotic therapy in those with and without neutropenia.

\section{Materials and methods Design and setting}

The present study is a secondary analysis of a matched case-control study performed in the ICU of Instituto Nacional de Câncer (INCa), Rio de Janeiro, Brazil. Details of the study design, definitions and data collection are provided elsewhere [10]. Briefly, during the study period (January 2003 to July 2007), every adult cancer patient ( $\geq 18$ yrs) that required ICU admission due to life-threatening complications was consecutively enrolled. Patients in complete remission of more than 5 yrs, those with an ICU stay less than $24 \mathrm{hrs}$ and readmissions were not considered. The ICU is a 10-bed medical-surgical unit specialized in the care of patients with cancer $[11,12]$, with the exception of bone marrow transplant patients.

This study was supported by institutional funds and did not interfere with clinical decisions related with patient care. The Local Ethics Committee approved the study $\left(\mathrm{N}^{\circ} 10 / 2003\right)$ and the need for informed consent was waived.

\section{Definitions, selection of participants and data collection}

Infection was defined as the presence of a pathogenic microorganism in a sterile milieu (such as blood or cerebrospinal fluid) and/or clinically suspected infection that justified the administration of antibiotics $[13,14]$. Sepsis severity was classified according to the consensus conference definitions [15].

Neutropenia was defined as a neutrophil count below $500 / \mathrm{mm}^{3}$ [2]. Neutropenia was further classified as chemotherapy related or unrelated. During the study period, from a prospective cohort of 1,332 consecutive cancer patients, 94 patients with neutropenia and wellmatched controls without neutropenia, in a 1:1 ratio, were compared [10]. For the present study, cancer patients with sepsis were segregated, 86 neutropenic and 68 non-neutropenic. Empiric antibiotic therapy was started in all septic cancer patients upon ICU admission according to to local guidelines and in accordance with the Infectious Diseases Society of America guidelines [2]. The prescription was not delayed by the collection of appropriate samples for microbiological cultures. At least two blood cultures were performed from independent venipunctures in each newly admitted patient. Additional samples for microbiological cultures were collected according to the suspected primary focus of infection.

Demographic, clinical and laboratory data were collected using standardized case report forms during the first day of ICU stay including main diagnosis for admission, the Simplified Acute Physiology Score (SAPS) II [16], the Sequential Organ Failure Assessment (SOFA) score [17], comorbidities, and cancer- and treatmentrelated data. For the purpose of the present study, individual organ failures were diagnosed in case of a SOFA score $\geq 2$ points in each domain [14]. In addition, patients receiving dialysis in the context of acute kidney injury and invasive mechanical ventilation (MV) on the first day of ICU were considered as having renal and respiratory failures regardless the SOFA score, respectively. The ICU and hospital mortality rates were also assessed.

Blood samples were obtained via an arterial line on admission and, subsequently, every morning at 07:00 hrs. Measurement of CRP was performed by means of an immunoturbidimetric method using a commercially available kit (Tina-quant CRP; Roche Diagnostics, Mannheim, Germany). The precision of the assay measured by means of the intra- and inter-assay coefficient of variation was $<7 \%$, the sensitivity $0.1 \mathrm{mg} / \mathrm{dL}$ and the detection limit $0.3 \mathrm{mg} / \mathrm{dL}$. C-reactive protein was measured during the first week of ICU stay at Day 1 (D1), D3, D5 and D7.

CRP concentrations at ICU admission and during the first week of sepsis course were analysed, comparing neutropenic with non-neutropenic septic critically ill cancer patients.

\section{Data processing and statistical analysis}

Data entry was performed by a single investigator (MS) and consistency was assessed with a rechecking procedure of a $10 \%$ random sample of patients. Data were screened in detail by three investigators (MS, JIFS, VCSD) for missing information, implausible and outlying values.

Continuous variables were reported as mean \pm standard deviation or median (25\% to $75 \%$ interquartile range, IQR) according to data distribution. Comparisons between groups were performed using the parametric unpaired and paired t-test, or the nonparametric MannWhitney $U$ test and Wilcoxon signed-rank test for continuous variables according to data distribution. The 
Chi-square test was used to carry out comparisons between categorical variables. Correlations were calculated by the Spearman's rank correlation. Time-dependent analysis of CRP was performed via General Linear Model univariate repeated-measures analysis using a split-plot design approach.

In all cases, statistical significance was defined as a two-tailed test with an alpha of 0.05. All statistical calculations were preformed using the PASW v. 18.0 for MAC (SPSS, Chicago, IL, USA).

\section{Results}

\section{Characteristics of the study population}

A total of 154 critically ill septic cancer patients were included in the present study, 86 with neutropenia, that represents all neutropenic septic cancer patients admitted in the ICU during the study period, and the remainder without neutropenia $(N=68)$. The patients' main characteristics are depicted in Table 1 . The sources of ICU admission were the operating room (10.4\%), emergency department (16.9\%) and wards (72.7\%) $(P=0.238$, comparing neutropenic vs. nonneutropenic patients). There were $105(68.2 \%)$ patients with hematological malignancies and 49 (31.8\%) with solid tumors $(P=0.569)$. The most frequent underlying malignancies were lymphomas $(N=59,38.3 \%)$, leukemias $(N=32,20.8 \%)$, gastrointestinal $(N=13$, $8.4 \%)$, multiple myeloma $(N=9,5.8 \%)$, urogenital $(N=$ $8,5.2 \%)$ and others $(N=33,21.4 \%)$. Previous anticancer treatments included surgery for tumor resections (3.9\%), chemotherapy $(72.7 \%)$ and radiation therapy (23.4\%). Comorbidities were indentified in 129 (83.8\%) patients and the most frequent were immunosuppression $(40.3 \%)$, arterial hypertension $(20.4 \%)$, acquired immunodeficiency syndrome $(8.4 \%)$, diabetes mellitus $(6.5 \%)$ and chronic obstructive pulmonary disease (6.5\%).

The length of ICU and hospital stay were (median (IQR)) 7.0 (10.3) days and 18.5 (23.6) days, respectively, without significant differences between neutropenic and non-neutropenic patients $(P=0.699$ and $P=0.111$, respectively). The overall ICU and hospital mortality rates were $72.1 \%$ and $79.2 \%$, respectively, without significant differences between study groups $(P=0.472$ and $P$ $=0.211$, respectively).

Most of the patients were admitted in the ICU in severe sepsis/septic shock (93.5\%) as well as with a severe degree of organ failure/dysfunction (SOFA at D1, $11.4 \pm 3.9$ points).

Almost two-thirds of the infections were microbiologically proven infections (65.1\%). As expected, the most frequent sites of infection were the lungs, abdomen and bloodstream infection. Gram-negative bacteria were responsible for $72.2 \%$ of the infection episodes and 26
(36.6\%) patients had polymicrobial (more than one infectious agent) infections.

\section{Impact of neutropenia on temperature and C-reactive protein}

At ICU admission, temperature in septic critically ill cancer patients was not significantly different in those presenting neutropenia in comparison with non-neutropenic patients $\left(37.2 \pm 1.5^{\circ} \mathrm{C}\right.$ vs. $36.8 \pm 1.5^{\circ} \mathrm{C}$, respectively, $P=0.119$ ) (Figure 1). Concerning CRP (Figure 1), we found that neutropenic septic cancer patients showed a significantly higher concentration, $25.9 \pm 11.2$ $\mathrm{mg} / \mathrm{dL}$, in comparison with CRP concentration from non-neutropenic patients, $19.7 \pm 11.4 \mathrm{mg} / \mathrm{dL}(P=$ 0.009). Additionally, among neutropenic patients CRP concentrations at ICU admission were not influenced by the severity of neutropenia $\left(<100 / \mathrm{mm}^{3}\right.$ vs. $\geq 100 / \mathrm{mm}^{3}$ neutrophils), $25.1 \pm 11.6 \mathrm{mg} / \mathrm{dL}$ vs. $26.9 \pm 10.9 \mathrm{mg} / \mathrm{dL}$, respectively $(P=0.527)$.

We also assessed the correlation between WCC and CRP concentration. We found a poor, whilst significant, correlation between these two variables $\left(\mathrm{r}_{s}=-0.252, P=\right.$ 0.012).

\section{C-reactive protein course in neutropenic and non- neutropenic patients}

Time dependent analysis of CRP (Figure 2) from D1 to D7 of antibiotic therapy showed an almost parallel course in both groups $(P=0.335)$, with almost no change from D1 to D3, followed by a significant decrease from D3 onwards; though the CRP concentration of neutropenic patients was, on average, higher in comparison to that of non-neutropenic patients. From D1 to D7, CRP concentration of neutropenic and nonneutropenic patients decreased from $25.9 \pm 11.2 \mathrm{mg} / \mathrm{dL}$ and $19.7 \pm 11.4 \mathrm{mg} / \mathrm{dL}$ at D1 to $14.1 \pm 9.1 \mathrm{mg} / \mathrm{dL}$ and $13.1 \pm 10.8 \mathrm{mg} / \mathrm{dL}$ at D7 $(P<0.001$ and $P=0.009$, respectively).

\section{Discussion}

We found among septic critically ill cancer patients a marked increase in CRP concentrations irrespective of the WCC, at ICU admission. Even though CRP concentrations in neutropenic patients were significantly higher, we found a poor correlation between WCC and CRP concentrations. Finally, our findings demonstrate that the course of CRP during the first week of antibiotic therapy was similar in neutropenic and non-neutropenic septic critically ill cancer patients.

Since inadequately treated infections can be rapidly fatal in neutropenic cancer patients, a great deal of clinical research on biomarkers has been published $[8,9]$. Several biomarkers, such as IL-6, IL-8, CRP, brain natriuretic peptides, procalcitonin, neopterin, have been 
Table 1 Baseline patients' characteristics and comparison between neutropenic and non-neutropenic patients

\begin{tabular}{|c|c|c|c|c|}
\hline & All Patients & Neutropenic & Non neutropenic & $P$-value \\
\hline N & 154 & 86 & 68 & \\
\hline Age (yrs) & $48.5 \pm 18.1$ & $47.0 \pm 17.8$ & $50.4 \pm 18.4$ & 0.248 \\
\hline Gender (M/F) & $94 / 60$ & $54 / 32$ & $40 / 28$ & 0.622 \\
\hline Type of cancer & & & & 0.569 \\
\hline Solid & 49 & 29 & 20 & \\
\hline Hematologic & 105 & 57 & 48 & \\
\hline Previous radiotherapy & 36 & 21 & 15 & 0.731 \\
\hline Previous Chemotherapy & 112 & 72 & 40 & 0.001 \\
\hline Previous surgery & 6 & 1 & 5 & 0.049 \\
\hline Non-invasive Ventilation & 15 & 14 & 1 & 0.002 \\
\hline Invasive mechanical Ventilation & 135 & 74 & 61 & 0.493 \\
\hline Vasopressors & 112 & 62 & 50 & 0.842 \\
\hline Type of infection & & & & 0.007 \\
\hline Pneumonia & 63 & 28 & 35 & \\
\hline Peritonitis & 15 & 7 & 8 & \\
\hline Urinary & 3 & 0 & 3 & \\
\hline Blood stream infections & 8 & 4 & 4 & \\
\hline Skin/Soft tissue infections & 7 & 4 & 3 & \\
\hline CNS infections & 1 & 0 & 1 & \\
\hline Other infections & 57 & 43 & 14 & \\
\hline SAPS II (points) & $62.2 \pm 16.8$ & $62.2 \pm 16.7$ & $62.5 \pm 16.8$ & 0.827 \\
\hline SOFA (Day 1) (points) & $11.4 \pm 3.9$ & $11.6 \pm 4.1$ & $11.2 \pm 4.1$ & 0.591 \\
\hline Sepsis severity & & & & 0.899 \\
\hline Sepsis & $10(6.5 \%)$ & $6(7 \%)$ & $4(5.9 \%)$ & \\
\hline Severe sepsis & $29(18.8 \%)$ & $17(19.8 \%)$ & $12(17.6 \%)$ & \\
\hline Septic shock & $111(74.7 \%)$ & $63(73.3 \%)$ & $52(76.5 \%)$ & \\
\hline Total white cell count $\left(/ \mathrm{mm}^{3}\right)$ & $1,400(14,636)$ & 352 (909) & $22,100(35,900)$ & $<0.001$ \\
\hline Temperature $\left({ }^{\circ} \mathrm{C}\right)$ & $37.0 \pm 1.5$ & $37.2 \pm 1.5$ & $36.8 \pm 1.5$ & 0.119 \\
\hline CRP (Day 1) (mg/dL) & $23.6 \pm 11.6$ & $25.9 \pm 11.2$ & $19.7 \pm 11.4$ & 0.009 \\
\hline Duration of mechanical ventilation (days) & $6.0(9.0)$ & $6.0(8.0)$ & $6.0(9.0)$ & 0.616 \\
\hline ICU length of stay (days) & $7.0(10.3)$ & $7.0(12.0)$ & $8.0(10.0)$ & 0.699 \\
\hline Hospital length of stay (days) & $18.5(23.6)$ & $20.5(25.0)$ & $16.5(21.0)$ & 0.111 \\
\hline ICU mortality & $111(72.1 \%)$ & $60(69.8 \%)$ & $51(75.0 \%)$ & 0.472 \\
\hline Hospital mortality & $122(79.2 \%)$ & $65(75.6 \%)$ & $57(83.8 \%)$ & 0.211 \\
\hline
\end{tabular}

Values expressed as $\mathrm{N}(\%)$, mean \pm standard deviation or median (interquartile range] according to type of data and data distribution; abbreviations: CNS, central nervous system; CRP, C-reactive protein; ICU, intensive care unit; SAPS II, Simplified Acute Physiology Score II; SOFA, Sequential Organ Failure Assessment score

evaluated in patients with febrile neutropenia to assess their performance in the diagnosis of infection [18-24], in the identification of the underlying agents [18-20,22,24], in the characterization of sepsis severity and outcome prediction [21,23-27]. However, information on biomarkers comparing neutropenic and nonneutropenic cancer patients are currently limited [28].

Among septic non-cancer patients there is substantial controversy concerning the potential effects of immunosuppression, in particular of corticosteroids, on CRP concentration, decreasing acute phase response independently of the treatment of infection [29-33].

In the present study, we clearly demonstrate that CRP, a major acute phase reactant protein, increases markedly in profoundly immunosuppressed cancer patients with sepsis. In other words, the acute phase reaction seems to remain unaffected by either chemotherapy or radiotherapy. Moreover, we found that septic neutropenic cancer patients had significantly higher CRP concentrations in comparison with non-neutropenic patients at ICU admission. Neutropenia reflects a profound state of immunosuppression representing a markedly increase susceptibility to infections [4]. In addition, neutropenic patients present an increased risk to acquire infections caused not only by "common" bacteria, but also by opportunistic agents, like virus and fungi, secondary to a decrease cellular and humoral immunity [4]. In addition, the size of the inoculum necessary to produce an 

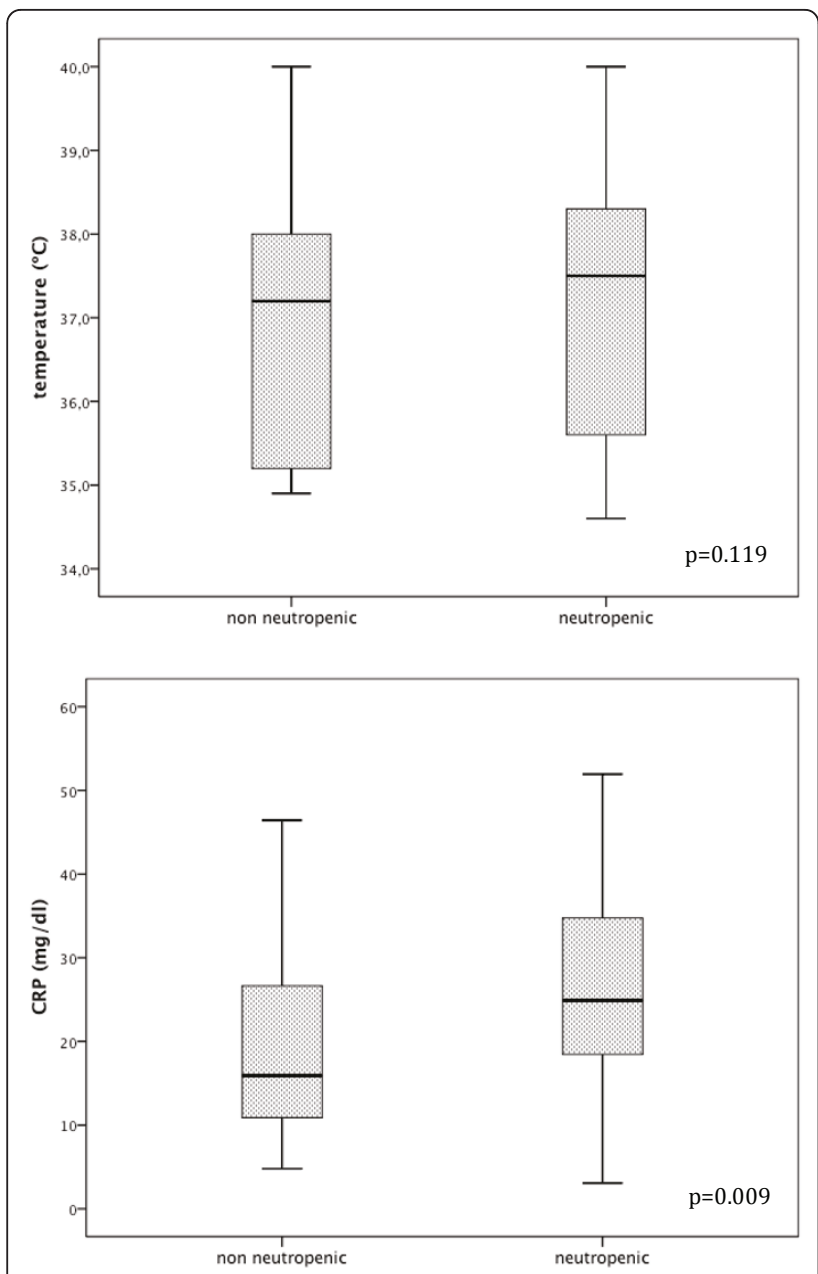

Figure 1 Temperature and C-reactive protein of neutropenic and non-neutropenic septic cancer patients at ICU admission. Comparison of temperature $\left({ }^{\circ} \mathrm{C}\right)$ and $\mathrm{C}$-reactive protein concentrations $(\mathrm{mg} / \mathrm{dL})$ at ICU admission between neutropenic and non-neutropenic septic critically ill cancer patients $(P=0.119$ and $P$ $=0.009$, respectively).

infection is reduced in neutropenic patients. In this context, we could hypothesize that microbiological agents would invade and proliferate easily in neutropenic patients, reaching a higher microbiological burden and also leading to a larger inflammatory response, reflected by a higher CRP concentration [34-36].

Consequently, our findings pointed to the clinical usefulness of CRP in critically ill septic cancer patients irrespective of the presence or absence of neutropenia, as well as, the degree of neutropenia.

Interestingly, other commonly used biomarkers in non-cancer patients, such as PCT, should be used with some reserve in neutropenia. The origin of PCT in the inflammatory response is not yet fully understood [37]. Moreover, it has been shown that in septic cancer patients with leukopenia PCT concentrations were lower

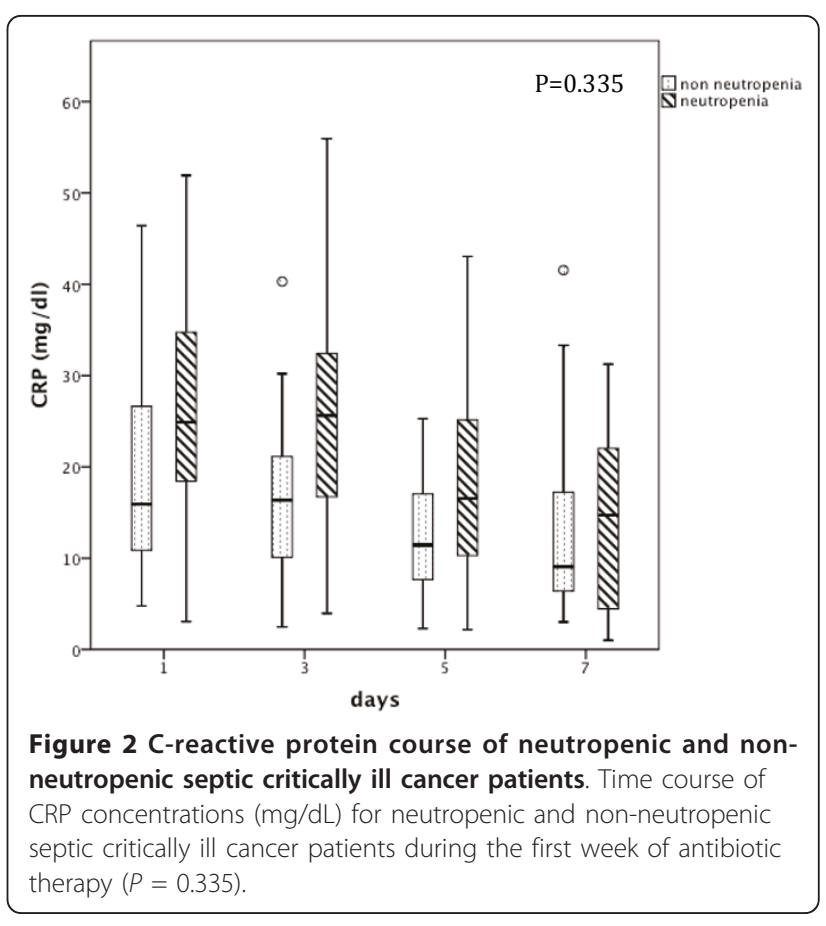

when compared with patients without leukopenia [28]. Consequently, it is possible to observe PCT values $<0.5$ $\mathrm{ng} / \mathrm{ml}$ in infected febrile neutropenic patients [9].

Besides, we recognize that the present study has some limitations. First, our study was an observational single centre study. Second, clinical and laboratory data assessing the recovery phase of neutropenia and factors that could have influenced the CRP course were not routinely collected. Third, since we only assessed CRP course during the first week of antibiotic therapy we cannot draw any conclusion concerning CRP course beyond D7. However, our study has also several important strengths. To date, this is the first study comparing CRP concentrations in septic cancer patients with and without neutropenia, and with a large cohort of septic neutropenic patients.

\section{Conclusions}

In conclusion, the results of this study provide valuable information concerning the CRP biology and timecourse in septic critically ill cancer patients. It was clear from our results that septic cancer patients express a full blown acute phase response with marked CRP elevations, and that this was particularly significant in the presence of neutropenia. Finally, CRP course was not influenced by the presence or absence of neutropenia. As a result, CRP could be a clinically useful bedside biomarker of infection in cancer patients irrespective of the WCC and the degree of immunosuppression. 


\section{Key messages}

- In the present study we showed that septic cancer patients express a full blown acute phase response with marked CRP elevations, and that this was particularly significant in the presence of neutropenia.

- The CRP course during the first week of antibiotic therapy was not influenced by the presence or absence of neutropenia.

- CRP could be a useful biomarker of infection in cancer patients irrespective of the WCC and the degree of immunosuppression.

\section{Abbreviations}

CRP: C-reactive protein; ICU: intensive care unit; IL: interleukin; IQR: interquartile range; MV: mechanical ventilation; SAPS II: Simplified Acute Physiology Score (SAPS) II; SIRS: systemic inflammatory response syndrome; SOFA: Sequential Organ Failure Assessment; WCC: white cell count.

\section{Acknowledgements}

Dr. Márcio Soares is supported in part by individual research grant from CNPq. This work was performed at the ICU of the Instituto Nacional de Câncer, Brazil.

\section{Author details}

'Polyvalent Intensive Care Unit, Hospital de São Francisco Xavier, Centro Hospitalar de Lisboa Ocidental, Estrada do Forte do Alto do Duque, 1449005 Lisboa, Portugal. ${ }^{2}$ CEDOC, Faculty of Medical Sciences, New University of Lisbon, Campo dos Mártires da Pátria, 130, 1169-056 Lisboa, Portugal. ${ }^{3}$ Postgraduation Program, Instituto Nacional de Câncer - INCA; Centro de Tratamento Intensivo - $10^{\circ}$ Andar, Praça Cruz Vermelha, 23, Rio de Janeiro RJ, CEP: 20230-130, Brazil. ${ }^{4}$ D'Or Institute for Research and Education, Rua Diniz Cordeiro, 30, Botafogo, Rio de Janeiro-RJ, Brazil.

\section{Authors' contributions}

PP, VCSD, MS and JIFS contributed to the study conception and design, carried out and participated in data analysis and drafted the manuscript. VCSD, MS and JIFS participated in acquisition of data. All authors read and approved the final version of the manuscript.

\section{Authors' information}

PP is coordinator of the Polyvalent Intensive Care Unit and president of the Antibiotic Commission of São Francisco Xavier Hospital. PP is Professor of Medicine of the Faculty of Medical Sciences from the New University of Lisbon, Portugal. VCSD is assistant physician of the ICU of the Instituto Nacional de Câncer, Rio de Janeiro, Brazil. MS and JIFS are associate investigators of D'Or Institute for Research and Education.

\section{Competing interests}

PP has received honoraria and served as advisor of Astra Zeneca, Ely-Lilly, Gilead, Janssen-Cilag, Merck Sharp \& Dohme, Novartis and Pfizer and received an unrestricted research grant from Brahms and Virogates. VCSD, MS and JIFS have no competing interests to declare.

Received: 5 March 2011 Revised: 10 April 2011 Accepted: 19 May 2011 Published: 19 May 2011

\section{References}

1. Soares M, Caruso P, Silva E, Teles JM, Lobo SM, Friedman G, Dal Pizzol F, Mello PV, Bozza FA, Silva UV, Torelly AP, Knibel MF, Rezende E, Netto JJ, Piras C, Castro A, Ferreira BS, Rea-Neto A, Olmedo PB, Salluh J: Characteristics and outcomes of patients with cancer requiring admission to intensive care units: a prospective multicenter study. Crit Care Med 2010, 38:9-15.

2. Hughes WT, Armstrong D, Bodey GP, Bow EJ, Brown AE, Calandra T, Feld R, Pizzo PA, Rolston KV, Shenep JL, Young LS: 2002 guidelines for the use of antimicrobial agents in neutropenic patients with cancer. Clin Infect Dis 2002, 34:730-751.

3. Sharma A, Lokeshwar N: Febrile neutropenia in haematological malignancies. J Postgrad Med 2005, 51:S42-48.

4. Hughes WT, Armstrong D, Bodey GP, Feld R, Mandell GL, Meyers JD, Pizzo PA, Schimpff SC, Shenep JL, Wade JC, et al: From the Infectious Diseases Society of America. Guidelines for the use of antimicrobial agents in neutropenic patients with unexplained fever. J Infect Dis 1990, 161:381-396.

5. Gaeta GB, Fusco FM, Nardiello S: Fever of unknown origin: a systematic review of the literature for 1995-2004. Nucl Med Commun 2006, 27:205-211.

6. Povoa P, Coelho L, Almeida E, Fernandes A, Mealha R, Moreira P, Sabino H: Early identification of intensive care unit-acquired infections with daily monitoring of C-reactive protein: a prospective observational study. Crit Care 2006, 10:R63.

7. Gabay C, Kushner I: Acute-phase proteins and other systemic responses to inflammation. N Engl J Med 1999, 340:448-454.

8. Sudhoff T, Giagounidis A, Karthaus M: Serum and plasma parameters in clinical evaluation of neutropenic fever. Antibiot Chemother 2000, 50:10-19.

9. Sakr Y, Sponholz C, Tuche F, Brunkhorst F, Reinhart K: The role of procalcitonin in febrile neutropenic patients: review of the literature. Infection 2008, 36:396-407.

10. Souza-Dantas VC, Salluh JI, Soares M: Impact of neutropenia on the outcomes of critically ill patients with cancer: a matched case-control study. Ann Oncol 2011.

11. Soares M, Salluh JI, Torres VB, Leal JV, Spector N: Short- and long-term outcomes of critically ill patients with cancer and prolonged ICU length of stay. Chest 2008, 134:520-526.

12. Soares M, Silva UV, Teles JM, Silva E, Caruso P, Lobo SM, Dal Pizzol F, Azevedo LP, de Carvalho FB, Salluh J: Validation of four prognostic scores in patients with cancer admitted to Brazilian intensive care units: results from a prospective multicenter study. Intensive Care Med 2010, 36:1188-1195

13. Vincent JL, Sakr Y, Sprung CL, Ranieri VM, Reinhart K, Gerlach H, Moreno R, Carlet J, Le Gall JR, Payen D: Sepsis in European intensive care units: results of the SOAP study. Crit Care Med 2006, 34:344-353.

14. Taccone FS, Artigas AA, Sprung CL, Moreno R, Sakr Y, Vincent JL: Characteristics and outcomes of cancer patients in European ICUs. Crit Care 2009, 13:R15.

15. Levy MM, Fink MP, Marshall JC, Abraham E, Angus D, Cook D, Cohen J, Opal SM, Vincent JL, Ramsay G: 2001 SCCM/ESICM/ACCP/ATS/SIS International Sepsis Definitions Conference. Crit Care Med 2003, 31:1250-1256.

16. Le Gall JR, Lemeshow S, Saulnier F: A new Simplified Acute Physiology Score (SAPS II) based on a European/North American multicenter study. JAMA 1993, 270:2957-2963.

17. Vincent JL, Moreno R, Takala J, Willatts S, De Mendonca A, Bruining H, Reinhart CK, Suter PM, Thijs LG: The SOFA (Sepsis-related Organ Failure Assessment) score to describe organ dysfunction/failure. On behalf of the Working Group on Sepsis-Related Problems of the European Society of Intensive Care Medicine. Intensive Care Med 1996, 22:707-710.

18. von Lilienfeld-Toal M, Dietrich MP, Glasmacher A, Lehmann L, Breig P, Hahn C, Schmidt-Wolf IG, Marklein G, Schroeder S, Stuber F: Markers of bacteremia in febrile neutropenic patients with hematological malignancies: procalcitonin and IL-6 are more reliable than C-reactive protein. Eur J Clin Microbiol Infect Dis 2004, 23:539-544.

19. Giamarellou H, Giamarellos-Bourboulis EJ, Repoussis P, Galani L, Anagnostopoulos N, Grecka P, Lubos D, Aoun M, Athanassiou K, Bouza E, Devigili E, Krcmery V, Menichetti F, Panaretou E, Papageorgiou E, Plachouras D: Potential use of procalcitonin as a diagnostic criterion in febrile neutropenia: experience from a multicentre study. Clin Microbiol Infect 2004, 10:628-633.

20. Erten N, Genc S, Besisik SK, Saka B, Karan MA, Tascioglu C: The predictive and diagnostic values of procalcitonin and C-reactive protein for clinical outcome in febrile neutropenic patients. J Chin Med Assoc 2004, 67:217-221.

21. Massaro KS, Costa SF, Leone C, Chamone DA: Procalcitonin (PCT) and Creactive protein (CRP) as severe systemic infection markers in febrile neutropenic adults. BMC Infect Dis 2007, 7:137. 
22. Prat C, Sancho JM, Dominguez J, Xicoy B, Gimenez M, Ferra C, Blanco S, Lacoma A, Ribera JM, Ausina V: Evaluation of procalcitonin, neopterin, Creactive protein, IL-6 and IL-8 as a diagnostic marker of infection in patients with febrile neutropenia. Leuk Lymphoma 2008, 49:1752-1761.

23. Hamalainen S, Juutilainen A, Matinlauri I, Kuittinen T, Ruokonen E, Koivula I, Jantunen E: Serum vascular endothelial growth factor in adult haematological patients with neutropenic fever: a comparison with Creactive protein. Eur J Haematol 2009, 83:251-257.

24. Buyukberber N, Buyukberber S, Sevinc A, Camci C: Cytokine concentrations are not predictive of bacteremia in febrile neutropenic patients. Med Oncol 2009, 26:55-61.

25. Ortega M, Rovira M, Almela M, de la Bellacasa JP, Carreras E, Mensa J: Measurement of C-reactive protein in adults with febrile neutropenia after hematopoietic cell transplantation. Bone Marrow Transplant 2004 33:741-744.

26. Hamalainen S, Juutilainen A, Kuittinen T, Nousiainen T, Matinlauri I, Pulkki K, Koivula I, Jantunen E: Serum amino-terminal pro-brain natriuretic peptide in hematological patients with neutropenic fever: a prospective comparison with C-reactive protein. Leuk Lymphoma 2010, 51:1040-1046.

27. Moon JM, Chun BJ: Predicting the complicated neutropenic fever in the emergency department. Emerg Med J 2009, 26:802-806.

28. Schuttrumpf $S$, Binder $L$, Hagemann T, Berkovic D, Trumper L, Binder C: Utility of procalcitonin concentration in the evaluation of patients with malignant diseases and elevated C-reactive protein plasma concentrations. Clin Infect Dis 2006, 43:468-473.

29. Monton C, Ewig S, Torres A, El-Ebiary M, Filella X, Rano A, Xaubet A: Role of glucocorticoids on inflammatory response in nonimmunosuppressed patients with pneumonia: a pilot study. Eur Respir J 1999, 14:218-220.

30. Confalonieri M, Urbino $R$, Potena A, Piattella M, Parigi P, Puccio G, Della Porta R, Giorgio C, Blasi F, Umberger R, Meduri GU: Hydrocortisone infusion for severe community-acquired pneumonia: a preliminary randomized study. Am J Respir Crit Care Med 2005, 171:242-248.

31. Mikami K, Suzuki M, Kitagawa H, Kawakami M, Hirota N, Yamaguchi H, Narumoto O, Kichikawa Y, Kawai M, Tashimo H, Arai H, Horiuchi T, Sakamoto Y: Efficacy of corticosteroids in the treatment of communityacquired pneumonia requiring hospitalization. Lung 2007, 185:249-255.

32. Bruns AH, Oosterheert JJ, Hak E, Hoepelman Al: Usefulness of consecutive C-reactive protein measurements in follow-up of severe communityacquired pneumonia. Eur Respir J 2008, 32:726-732.

33. Salluh Jl, Soares M, Coelho LM, Bozza FA, Verdeal JC, Castro-Faria-Neto HC, Silva JR, Bozza PT, Povoa P: Impact of systemic corticosteroids on the clinical course and outcomes of patients with severe communityacquired pneumonia: A cohort study. J Crit Care 2011, 26:193-200.

34. Lobo SM, Lobo FR, Bota DP, Lopes-Ferreira F, Soliman HM, Melot C, Vincent $J$ L: C-reactive protein levels correlate with mortality and organ failure in critically ill patients. Chest 2003, 123:2043-2049.

35. Lisboa T, Seligman R, Diaz E, Rodriguez A, Teixeira PJ, Rello J: C-reactive protein correlates with bacterial load and appropriate antibiotic therapy in suspected ventilator-associated pneumonia. Crit Care Med 2008, 36:166-171.

36. Rello J, Lisboa T, Lujan M, Gallego M, Kee C, Kay I, Lopez D, Waterer GW: Severity of pneumococcal pneumonia associated with genomic bacterial load. Chest 2009, 136:832-840.

37. Christ-Crain M, Opal SM: Clinical review: the role of biomarkers in the diagnosis and management of community-acquired pneumonia. Crit Care 2010, 14:203.

doi:10.1186/cc10242

Cite this article as: Póvoa et al:: C-reactive protein in critically ill cancer patients with sepsis: influence of neutropenia. Critical Care 2011 15:R129.

\section{Submit your next manuscript to BioMed Central and take full advantage of:}

- Convenient online submission

- Thorough peer review

- No space constraints or color figure charges

- Immediate publication on acceptance

- Inclusion in PubMed, CAS, Scopus and Google Scholar

- Research which is freely available for redistribution

Submit your manuscript at www.biomedcentral.com/submit
Biomed Central 